\title{
Trends and patterns in annually burned forest areas and fire weather across the European boreal zone in the $20^{\text {th }}$ and early $21^{\text {st }}$ centuries
}

\author{
Igor Drobyshev a,b,d, ", Nina Ryzhkova ${ }^{\mathrm{d}}$, Jonathan Eden ${ }^{\mathrm{e}}$, Mara Kitenberga ${ }^{\mathrm{c}}$, Guilherme Pinto ${ }^{\mathrm{h}}$, \\ Henrik Lindberg ${ }^{\mathrm{f}}$, Folmer Krikken ${ }^{\mathrm{g}}$, Maxim Yermokhin ${ }^{\mathrm{i}}$, Yves Bergeron ${ }^{\mathrm{b}}$, Alexander Kryshen ${ }^{\mathrm{d}}$ \\ ${ }^{a}$ Southern Swedish Forest Research Centre, Swedish University of Agricultural Sciences, P.O. Box 49, 23053 Alnarp, Sweden \\ ${ }^{\mathrm{b}}$ Institut de recherche sur les forêts, Chaire de recherche du Canda en en aménagement forestier durable, Université du Québec en Abitibi-Témiscamingue (UQAT), 445 \\ boul. de l'Université, Rouyn-Noranda, Québec, J9 x 5E4, Canada \\ ${ }^{\mathrm{c}}$ Latvian State Forest Research Institute Silava, Rigas street 111, LV-2169 Salaspils, Latvia \\ ${ }^{\mathrm{d}}$ Forest Research Institute of the Karelian Research Centre of the Russian Academy of Sciences, 11 Pushkinskaya St., 185910 Petrozavodsk, Republic of Karelia, Russia \\ e Centre for Agroecology, Water and Resilience (CAWR), Coventry University, UK \\ ${ }^{\mathrm{f}}$ Häme University of Applied Sciences (HAMK), PO Box 230, 13101 Hämeenlinna Finland \\ ${ }^{g}$ The Royal Netherlands Meteorological Institute (KNMI), Postbus 201, 3730 AE De Bilt, Netherlands \\ ${ }^{\mathrm{h}}$ German Centre for Integrative Biodiversity Research (iDiv) Halle-Jena-Leipzig, Puschstrasse 4, 04103, Leipzig, Germany \\ ${ }^{\mathrm{i}}$ V. F. Kuprevich Institute of Experimental Botany, National Academy of Sciences of Belarus, Independence Ave. 66, 220072, Republic of Belarus, Minsk
}

\section{A R T I C L E I N F O}

\section{Keywords:}

Forest fires

Disturbance regimes

Climate-fire interactions

Trends in drought conditions

Climate-related risks

\begin{abstract}
A B S T R A C T
Fire remains one of the main natural disturbance factors in the European boreal zone and understanding climatic forcing on fire activity is important for projecting effects of climate change on ecosystem services in this region. We analyzed records of annually burned areas in 16 administrative regions of the European boreal zone (countries or administrative units within countries) and fire weather variability to test for their spatio-temporal patterns over the 1901-2017 period.

Over the 1992-2017 period, the region exhibited large variability in forest fire activity with the fire cycles varying from $\sim 1600$ (St. Petersburg region) to $\sim 37000$ years (Finland). The clustering of administrative units in respect to their burned area, suggested the presence of sub-regions with synchronous annual variability in burned areas. Large fire years (LFYs) in each of the clusters were associated with the development of the high pressure cell over or in immediate proximity of the regions in question in July, indicating climatic forcing of LFYs. Contingency analysis indicated that there was no long-term trend in the synchrony of LFYs observed simultaneously in several administrative units. We documented a trend towards higher values of Monthly Drought Code (MDC) for the months of April and May in the western (April) and northern (April and May) sections. The significant positive correlation between biome-wide fire activity index and June SNAO (Summer North Atlantic Oscillation) $(r=0.53)$ pointed to the importance of large-scale atmospheric circulation, in particular the summer European blocking pattern, in controlling forest fires across EBZ. The forest fire activity of the European boreal zone remains strongly connected to the annual climate variability. Higher frequency of strongly positive SNAO states in the future will likely synchronize years with a large area burned across the European boreal zone.
\end{abstract}

\section{Introduction}

Forest fires have been the main natural disturbance force in the
European boreal zone (EBZ) over the Holocene, controlling the evolution of vegetation cover and contribution of this biome to the global geochemical cycles (Conard and Ivanova, 1997; Pitkanen and Huttunen,

Abbreviations: AMO, Atlantic Multidecadal Oscillation; EBZ, the European Boreal Zone; DC, Drought Code; ENSO, El Niño-Southern Oscillation; FAI, Fire Activity

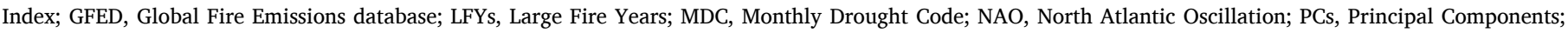
PDO, Pacific Decadal Oscillation; SNAO, Summer North Atlantic Oscillation.

* Corresponding author.

E-mail addresses: Igor.Drobyshev@slu.se, Igor.Drobyshev@uqat.ca (I. Drobyshev), nina.ryzhkova@slu.se (N. Ryzhkova), ac6218@coventry.ac.uk (J. Eden), mara.

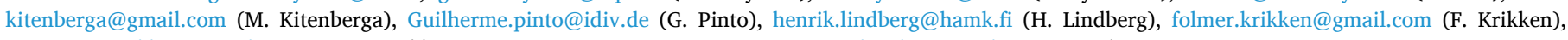
maxim.yermokhin@gmail.com (M. Yermokhin), Yves.Bergeron@uqat.ca (Y. Bergeron), akryshen@mail.ru (A. Kryshen). 
1999; Carcaillet et al., 2007; Greisman and Gaillard, 2009; Ohlson et al., 2011; Clear et al., 2014; Kharuk et al., 2021). Since the 19th century, the EBZ has been experiencing an increasingly pronounced west-east gradient in fire activity. In its western sections, the fires have been largely suppressed since late 19th century with its modern fire cycle reaching 10-20k years (Drobyshev et al., 2012). In contrast, the eastern fringes of EBZ have a fire cycle of about 300-600 years (Drobyshev and Niklasson, 2004), i.e. the levels reconstructed prior to the onset of intensive forest use across Fennoscandia (Niklasson and Granström, 2000). Variability in climate conditions, modern and historical patterns of forest use, and the overall forest accessibility for the forest industry are likely the main drivers of this gradient. Although there is a general consensus on the importance and the mechanisms of human impact on geographical variability of fire activity across the EBZ (Granström and Niklasson, 2008), the role of climate in shaping this and future geographical gradients in fire activity remains poorly understood. Indeed, the vast majority of the studies looking at climate-fire interactions within the European boreal zone have been done in Fennoscandia (Prentice et al., 1991; Drobyshev et al., 2016; Lehtonen et al., 2016; Aakala et al., 2018; Krikken et al., 2019), a region experiencing a much stronger influence of North Atlantic climate, as compared to more easterly located sections of the EBZ. The increase in climate continentality towards the easterly section of the EBZ is of particular interest for understanding the response of forest fire regimes to climate variability. This is because previous studies have pointed to higher sensitivity of more continental boreal forests to historic climate changes (Drobyshev et al., 2014, 2017).

Climatic forcing on fire activity affects multiple ecosystem services provided by boreal forests (Gauthier et al., 2015). Recent years with a large amount of burned area (such as during 2018 in Sweden) occurred in the parts of the EBZ where forest management and fire suppression policies have been generally effective in controlling the forest fires (Pinto et al. 2020). This observation and the heavy reliance of all regional economies on forest resources both call for a systematic analysis of the modern and projected patterns in fire activity. Here we provide a synthesis of the observational records of the annual burned areas resolved at the scale of large administrative regions within EBZ. In doing so, we discuss spatio-temporal patterns in fire activity, its association with climatic fire proxies, and the synchrony of the occurrence of years with a large forest area burned (later referred to as large fire years, LFYs). We put forward three hypotheses, all tested over the 20th and early 21st centuries: (H1) over the studied timeframe, LFYs exhibited a trend towards higher synchrony across the EBZ, (H2) fire weather hazard increased in EBZ or some of its sections, and (H3) there is a relationship between forest fire activity in EBZ and large-scale patterns of atmospheric circulation. To test these hypotheses, we used cluster analyses to partition the EBZ into regions of temporally synchronous annual fire activity. We based our clustering on the annual dynamics of fire activity only, not considering the properties of the analyzed regions nor their geographical positions.

To widen the time horizon of the analyses, we reconstructed 117year long chronologies of annually burned forest areas for members of the clusters with the highest correlation between the observational fire record and the climatological proxy of fire weather. Finally, we analyzed the association of fire activity with temperature, precipitation, $500 \mathrm{mPa}$ pressure fields and indices of atmospheric circulation to deduce the large-scale climatological controls of fire activity.

\section{The study area}

\subsection{The climate of the region}

The EBZ is generally characterized by a moist, cool continental climate, ranging from subarctic conditions in the north and east to cool temperature conditions in the west. The region is under the heavy influence of westerlies and Arctic air masses and is mostly of the Atlantic type (Suppl. Info. Fig. 1A through Fig. 1D). Mean annual temperatures are generally low but vary considerably across the region, dominated by a notable west-east temperature gradient. During the winter, the western sections of the EBZ is warmer than its easterly sections: in Southern Scandinavia monthly mean temperature is generally within a few degrees of $0^{\circ} \mathrm{C}$, while in the Komi republic average monthly temperatures typically fall to between $-15{ }^{\circ} \mathrm{C}$ and $-20^{\circ} \mathrm{C}$. In contrast, summer temperature shows a clear South-North pattern augmented with the altitude gradient in the Swedish Mountains. The highest mean temperatures in excess of $20^{\circ} \mathrm{C}$ found in southern parts of the interior (e.g. Belarus) while the lowest temperatures are found in the northern and western regions where subarctic and maritime influences respectively continue to dominate; temperatures below $10^{\circ} \mathrm{C}$ are typical to much of the Swedish mountains, northern Finland and Norway. Precipitation varies substantially between the Atlantic coast and mountainous regions of Norway and Sweden, and the considerably drier continental interior. During winter, precipitation is generally between 30 to $50 \mathrm{~mm}$ per month in the most of the EBZ interior but can exceed $300 \mathrm{~mm}$ per months at the Atlantic coast of Norway. Summer precipitation in the EBZ is generally higher with the mean monthly values of around 60 to $90 \mathrm{~mm}$, with the Norway and western Sweden receiving between 120 and $180 \mathrm{~mm} /$ month, on average. The snow-free period lasts from April-May to October-November in the most of the EBZ (Suppl. Info. Fig. 1E through Fig. 1H). Prolonged periods of drought, while uncommon, are anticipated during the 21 st century to be increasingly associated with soil moisture deficit and earlier snow melt during spring (Ruosteenoja et al., 2018).

\subsection{The regional vegetation cover}

The forests of the region stretch over four bioclimatic domains, including northern boreal forests, mid-and south boreal forests, and boreo-nemoral forests (Ahti et al., 1968; Aleksandrova and Yurkovskaya, 1989) (Fig. 1A). EBZ is the area of relatively low tree canopy diversity with limited variability in the canopy structures across its W-E extend. Scots pine (Pinus sylvestis L.) and Norway spruce (Picea abies (L.) $\mathrm{H}$. Karst) dominate the mid- and late successional stages, while downy birch (Betula pubescens Ehrh.), silver birch (B. pendula Roth.), grey alder (Alnus incana (L.) Moench) and aspen (Populus tremula L.) prevail in the early successional forests. Siberian larch (Larix sibirica Lebed.) occur as a generally minor contributor to the forest canopies on the eastern fridges of EBZ. Boreo-nemoral forests commonly contain a considerable proportion of hardwoods, the most important of them being pedunculated oak (Quercus robur L.) and European beech (Fagus sylvatica L.). Despite low canopy diversity, the region features a high variability in the types and abundance of forest fuels due to the mosaic of forest patches with contrasting growing conditions and times since the last disturbance. Mesic and compositionally diverse forests with a varying proportion of coniferous and deciduous species prevail in this biome. Xeric forests, typically with abundant Scots pine and Cladonia spp. lichen on the forest floor can be found predominantly across the northern sections of the EBZ. Forests of the region often feature a continuous carpet-like layer with mosses Pleurozium schreberi (Brid.) Mitt, Hylocomium splendens (Hedw.) Schimp., Dicranum spp.) and lichen (Cladonia spp.). The layer provides a common flammable fuel bed, where the majority of forest fires ignite and spread (Schimmel and Granström, 1996). Mires and hydric sites with abundant yet typically wet fuels are common in the EBZ, although they rarely dominate at the sub-regional scales.

Available annual fire activity and respective reconstructions represented the regions in their entirety, making it impossible to partition fire records among different vegetation types. It follows that some of the fires contributing to the regional statistics might have occurred in the tundra and/or peatlands. However, the vast majority of the studied administrative units were located in the broadly understood boreal region. 
A.

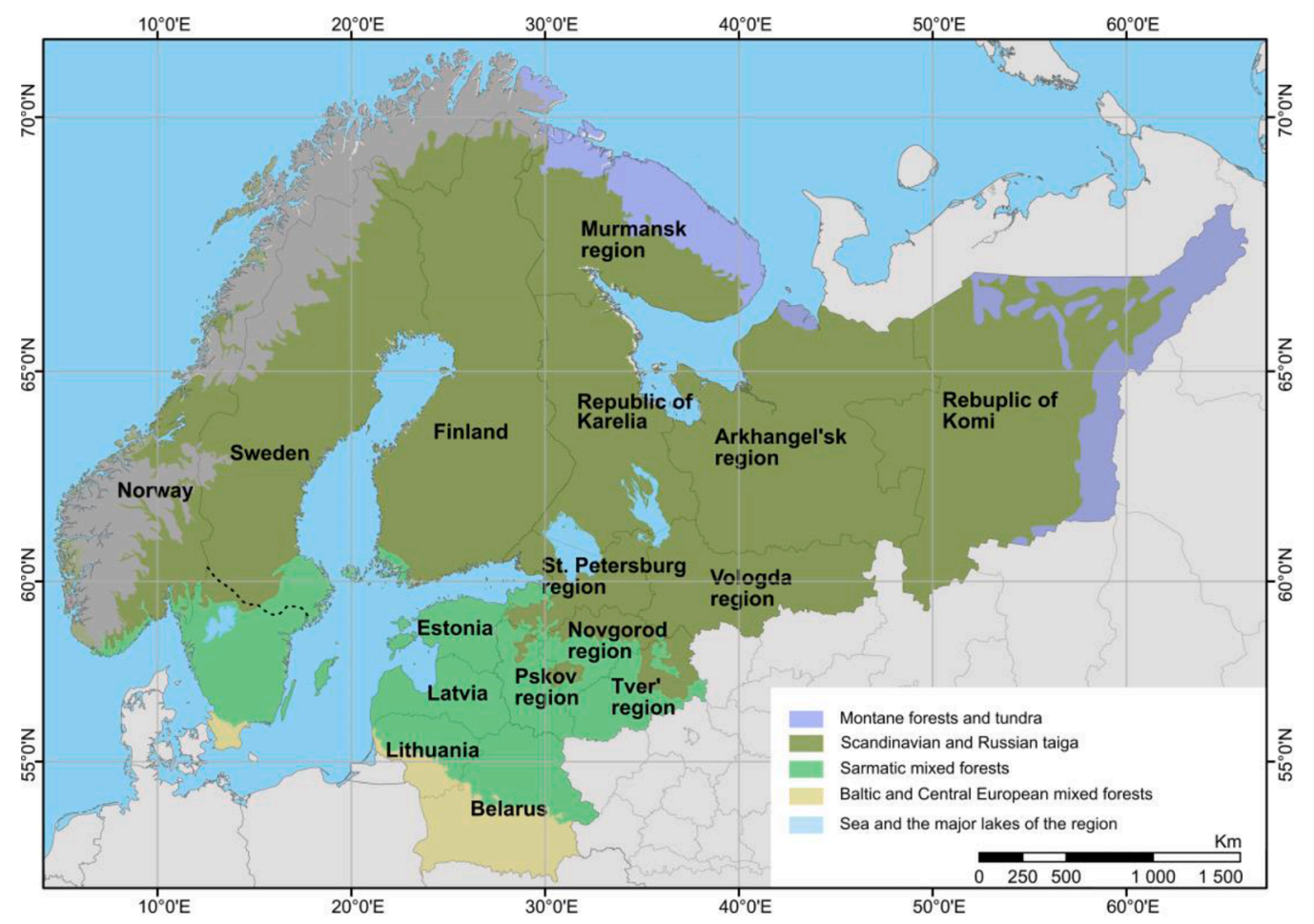

B.

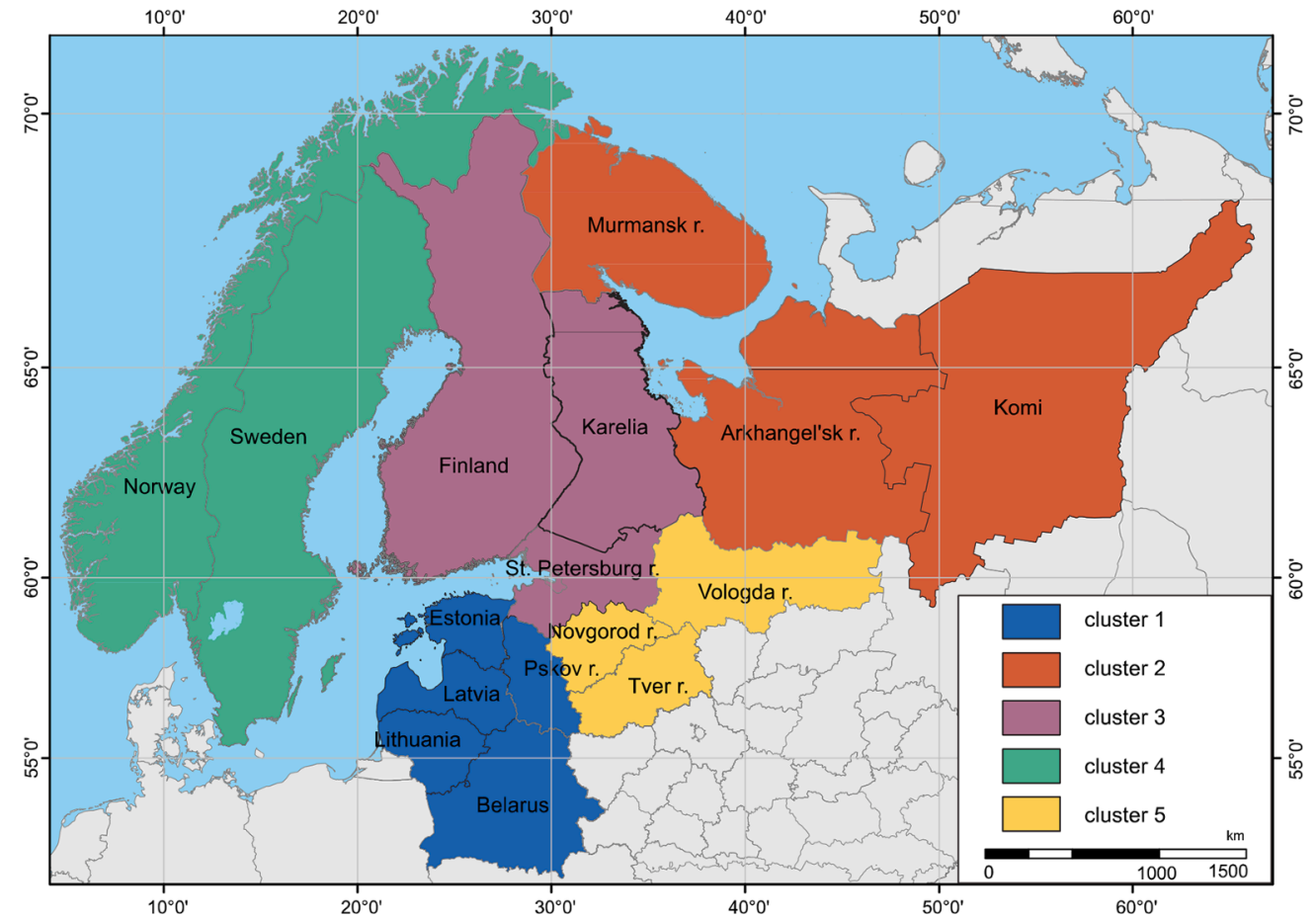

Fig. 1. The geographic scope of the study with the administrative units providing the fire data (A) and the clustering results based on their annual forest fire activity (B). On Fig. 1A, the dashed black line indicates the border between Southern and Northern Sweden, adopted in this study. In $\mathrm{B}$, the classification is a result of the hierarchical clustering over the period between 1901-2017. Each cluster represents a group of administrative units with synchronous annual fire activity. The clustering diagram is presented in Fig. 2.

\section{Methods}

\subsection{Data sources}

In this study, we operated with the fire and climate data resolved at the scale of large administrative units, ranging in size from $45 \bullet 10^{3} \mathrm{~km}^{2}$ (Estonia) to $417 \cdot 10^{3} \mathrm{~km}^{2}$ (Russian Komi republic) (Fig. 1). In the case of Sweden $\left(450 \bullet 10^{3} \mathrm{~km}^{2}\right.$ ), the country was divided into southern and northern sections, based on the earlier analyses of its modern fire activity (Drobyshev et al., 2012). Compilation of the modern fire records 
presented two main challenges: different temporal resolution of available datasets (e.g. daily in Sweden and annual for the majority of the administrative units analyzed), and varying lengths of the records (Table 2). We elected to conduct the analyses on the annual scale to maximize their temporal coverage and to focus on the climate-fire linkages extending over the whole fire season. We used two sources of data on annually burned forest areas: official forest fire statistics maintained by respective state authorities and the dataset on burned areas from the Global Fire Emissions Database (GFED) resolved at 0.25 degrees (Giglio et al., 2013). Official fire statistics for the administrative regions of Russia was not available beyond 2012 and GFED was used to extend these records to 2016. In bridging the official (state-provided) and GFED data, we tested for the correlation between official and satellite-based records over the overlapping period (1997-2012). For several Russian administrative units, we observed a non-significant correlation between official data and the GFED-based record. Two possible contributors to low correlation values were the quality of the official fire statistics, which has been previously reported to underestimate the levels of fire activity (Soja et al., 2004) and the inclusion in the GFED estimates of all land area (i.e. both forest and non-forest lands). In this case, the correlation between Monthly Drought Code (MDC) and the annually burned areas was used to extend the record (see the following sub-sections).

Our study does not target the origin and the spatio-temporal patterns of fire ignitions. The reason for this is two-fold. First, the spatial coverage of these data is limited to Fennoscandia, mostly concerns lightning ignitions (Granström, 1993; Larjavaara et al., 2005; Wallenius et al., 2010) and few decades. Second, the vast majority of information on effective fire ignitions is not obtained through observation, but relies on a set of assumptions and/or guesses. Indeed, as a vast majority of ignitions are not directly observed, their origin being generally deduced based on the climatological and landscape contexts (e.g. presence of human and human infrastructure). Instead, a large volume of research in the boreal region has documented a strong relation between the regional area burned and metrics of climatological fire hazard (Skinner et al., 1999; Girardin et al., 2009; Drobyshev et al., 2012; Eden et al., 2020). These observations further justify the use of burned area records and climatological drought proxies to study biome-wide trends in fire activity.

\subsection{Monthly Drought Code (MDC) calculation}

To contrast annually resolved annually burned areas with the local fire climate, we calculated monthly drought codes (MDC) for the territory of each administrative unit by aggregating MDCs for the grid cells with their geographical centers located within the respective units. MDC is the monthly version of the Drought Code (DC), which is a component of the Canadian Forest Fire Weather Index (Girardin and Wotton, 2009). The DC was originally developed to capture moisture content of deep layers of the forest floor (Turner, 1972). The numerical value of MDC reflects a water holding capacity of $100 \mathrm{~mm}$. Value of MDC are numerically comparable with the values of the drought code, the original component of the Canadian Fire Weather System, resolved with the daily-resolution (Girardin and Wotton 2009). Higher MDC are indicative of the higher climatological fire hazard, the values above 350 considered as indicative of very strong hazard. Previous studies revealed a strong connection between MDC and regional fire activity across the boreal zone of the Northern Hemisphere (Girardin et al., 2009; Drobyshev et al., 2012; Eden et al., 2020). The MDC calculation used the monthly precipitation total and maximum monthly temperatures from the CRU TS v. 4.02 (Harris et al., 2014). Details on the protocol of MDC calculation is available in the Supplementary Information Text 1.

\subsection{Selection of the "best" cluster members}

Efficiency of fire suppression, maximum length of burned area chronologies and the quality of these data varied within each of the identified clusters. We, therefore, selected a single administrative unit within each cluster as "the best representative" of that cluster for subsequent analyses. The primary criterion for selection was the strongest correlation of unit-specific burned area chronologies with the MDC predictors within the cluster in question, and the secondary criterion was the longest length of the burned area chronology. Adopting this approach allowed us to partially remove spatial correlation across regions and to obtain a subset of the initial data with the supposedly highest data quality. The fire record of selected administrative units was extended over the entire 20th century, using its linear relationship with one or a group of MDC variables (see next section).

\subsection{Reconstruction of fire activity}

To identify the most skillful predictor of the unit-specific burned area chronology, we ran response function analyses with the full range of combinations of the monthly, mean bi-monthly and seasonal MDCs and assessed the unique contributions of MDC variables into fire dynamics for each unit. Response function analysis is a combination of (a) principal component analysis, used to generate a reduced number of orthogonal predictors (principal components, PCs) from a highly autocorrelated set of climate variables, and (b) regression analysis, which parameterizes the relationship between PC and the predictand, in this case - an chronology of annually burned areas. For this step, we used the function $d c c$ with the stationary bootstrapping option of the R package treeclim (Zang and Biondi, 2015). An identified set of variables was used to reconstruct the annually burned areas outside the period covered by the observational record. To this end, we divided the observational fire record into equal calibration and verification subsets and assessed the quality of reconstruction by a combination of three statistics: reduction of error (RE), coefficient of efficiency (CE), and the Durban-Watson statistic (DW) (Cook et al., 1994). We considered reconstruction skillful, if it produced a CE value above zero. We calculated the reconstruction statistics with the function skills in the R package treeclim (Zang and Biondi, 2015).

\subsection{Contingency analyses}

To test for the changes in synchrony in the occurrence of LFY over the $20^{\text {th }}$ and $21^{\text {st }}$ centuries (H2), we used contingency analysis. The rationale for considering LFY only in the contingency analysis was two-fold. First, we wanted to extract the portion of the record, which supposedly reflected the strongest degree of climate forcing upon regional fire activities. Across the boreal and temperate zones, the degree of regionally (or synchrony) in the fire activity has been shown to be positively correlated to the degree of climatic impact upon fire (Swetnam, 1993; Falk et al., 2011; Drobyshev et al., 2015). By focusing exclusively on the LFY's, we disregarded years for which the contribution of non-climatic factors to the amount of annually burned areas was likely higher. Second, LFYs commonly provide one order of magnitude larger impacts, both in terms of ecology and economy, as compared to "average" years (Stocks et al., 1998), and understanding the pattern of their occurrences is, therefore, of critical interest for developing mitigation strategies.

We identified LFYs as years belonging to the $90 \%$ distribution percentile in the 117 year long (1901-2017) chronology of annually burned areas for the respective administrative unit. The contingency analysis was done, therefore, on the composite (observational + reconstructed) LFY chronology for the "best" representative of each cluster, i.e. the unit (administrative region) whose record had the highest correlation with MDC predictors among members of respective cluster.

We assessed the theoretically expected frequencies of LFYs observed simultaneously (i.e. in the same year) in different clusters, by calculating joint probabilities of LFYs under the random process. We assumed the binominal distribution of the LFYs: 
$p(X)=\frac{N !}{X !(N-X)} p^{x} q^{N-X}$,

where $N$ was the total number of clusters in analysis; $X$ - the number of clusters with LFY in a single year; $p$ - the probability of LFY in a cluster, and $q$ - the inverse of this probability. The differences between expected and observed frequencies were estimated with the Chi-square test (Sokal and Rolf, 1995). Since Chi-square test does not provide the means to assess the statistical significance of the occurrence of a particular synchrony level, we bootstrapped the dataset 1000 times to obtain the distribution of LFY occurrences to estimate the 0.90 distribution quantile for each synchrony level (i.e. from 0 to 5 , the total number of units in this analysis) under the assumption of a random process. We, therefore, considered the exceedance of the observed frequencies over the value of 0.9 quantile as an indication that a particular synchrony level was associated with statistically significant departure from the random process. We repeated this analysis for the July MDC values, which represented the 0.90 quantile of the MDC distribution for respective administrative units. The choice of July MDC was based on the observation that this month was consistently selected as a predictor for reconstructions of unit-specific chronology of annually burned areas (Suppl. Info. Table 1).

\subsection{Superposed epoch analysis}

We evaluated the association of LFYs in the selected administrative units with July $500 \mathrm{hPa}$ pressure fields, using the Hadley Centre Sea Level Pressure dataset (HadSLP2) (Allan and Ansell, 2006). Superimposed epoch analysis, or composite analysis (Kelly and Sear, 1984), was used to quantify deviations of the pressure fields during the LFYs from the long-term means and to evaluate the geographic pattern of pressure anomalies associated with LFYs in each cluster. We run this analysis on the periods with available observational data in the respective cluster member, which was selected based on the results of cluster analysis and of correlation between MDC and fire data (Table 2). The statistical significance of the results was estimated through bootstrapping of the long-term distribution of July mean values for respective periods.

\subsection{Trends in fire weather}

We used MDC chronologies to test for century long trends in fire weather (H3). First, to test for the temporal trends in fire weather conditions we regressed, cell-wise, monthly MDC chronologies for the
Table 2

Reconstruction skill of the monthly drought code (MDC) in respect to the annual amount of burned areas in the studied administrative units. A.CE and B.CE refer to the values of the coefficient of efficiency, a measure of reconstruction skill with split calibration-verification scheme (A - early verification and late reconstruction, $\mathrm{B}$ - the opposite). $\mathrm{R}^{2}$ indicates the amount of variability explained by MDC, when linearly regressed against the amount of annually burned areas over the period with available observational fire data. Cluster identity refers to cluster IDs on Figs. 1B and 2. Underlined are the units selected as "the best representative" of a cluster.

\begin{tabular}{|c|c|c|c|c|c|}
\hline $\begin{array}{l}\text { Administrative } \\
\text { unit }\end{array}$ & $\begin{array}{l}\text { Period with } \\
\text { observational data }\end{array}$ & $\begin{array}{l}\text { Cluster } \\
\text { identity }\end{array}$ & A.CE & B.CE & $\mathrm{R}^{2}$ \\
\hline Norway & 1913-2017 & 4 & 0.048 & 0.06 & 0.035 \\
\hline $\begin{array}{l}\text { Northern } \\
\text { Sweden }\end{array}$ & $\begin{array}{l}1942-1975 \& \\
1996-2017\end{array}$ & 4 & 0.336 & 0.331 & 0.369 \\
\hline $\begin{array}{l}\text { Southern } \\
\text { Sweden }\end{array}$ & $\begin{array}{l}1942-1975 \& \\
1996-2017\end{array}$ & 4 & 0.145 & 0.163 & 0.224 \\
\hline Lithuania & $1930-2017$ & 1 & 0.349 & -0.559 & 0.391 \\
\hline Latvia & 1922-2017 & 1 & -0.35 & 0.013 & 0.13 \\
\hline Finland & 1901-2017 & 3 & 0.114 & 0.029 & 0.104 \\
\hline Belarus & $1901-1958$ & 1 & 0.309 & 0.41 & 0.584 \\
\hline Estonia & 1921-2017 & 1 & 0.031 & 0.162 & 0.169 \\
\hline Pskov region & 1992-2017 & 1 & 0.32 & -0.109 & 0.487 \\
\hline Novgorod region & 1992-2017 & 5 & 0.403 & -0.082 & 0.695 \\
\hline $\begin{array}{l}\text { St Petersburg } \\
\text { region }\end{array}$ & $1966-2017$ & 5 & -0.449 & 0.263 & 0.55 \\
\hline Tver region & 1992-2017 & 5 & 0.468 & 0.297 & 0.746 \\
\hline $\begin{array}{l}\text { Republic of } \\
\text { Karelia }\end{array}$ & $1992-2017$ & 3 & 0.169 & 0.592 & 0.571 \\
\hline $\begin{array}{l}\text { Murmansk } \\
\text { region }\end{array}$ & 1992-2017 & 2 & 0.579 & 0.333 & 0.572 \\
\hline Vologda region & 1992-2017 & 5 & 0.1 & 0.002 & 0.27 \\
\hline $\begin{array}{l}\text { Archangelsk } \\
\text { region }\end{array}$ & $1992-2017$ & 2 & 0.177 & 0.065 & 0.281 \\
\hline Komi & 1950-2017 & 2 & 0.229 & 0.135 & 0.216 \\
\hline
\end{tabular}

period of April through September against the global mean surface temperatures (GMST, (Hansen et al., 2010)) for the entire EBZ over the 1901-2017 period. We used principal component analysis to study the geographical variability in the behavior of July MDC, a common predictor of the annually burned areas in sub-regions of EBZ (as revealed by the analyses done in this study), over the complete (1901-2017) and the recent (1950-2017) period to map the loadings of the principal components over the study region. To this end, we ran principal component analysis (PCA) on the July MDC chronologies and constructed the distance matrix based on the Euclidean distances, using functions prcomp and dist of the R package stats, respectively (R Development Core Team,

Table 1

Descriptors of the administrative units whose fire data were used in the analyses. For the purposes of this table, Southern Sweden includes Götaland and Svealand and Northern Sweden includes Norrland. The St. Petersburg region does not include the City of St. Petersburg itself. FCmean refers to the fire cycle (FC) calculated on the mean annually burned forest area during the period between 1992-2017. FCextreme refers to the fire cycle calculated on the three years with the largest amount of area burned in the respective unit. Data sources used to compile this table are available in Supplementary Information Appendix 1.

\begin{tabular}{|c|c|c|c|c|c|c|}
\hline Unit name & Area, $\mathrm{km}^{2 *} * 10^{3}$ & Forested area, $* 10^{3}$ ha & Population, ${ }^{*} 10^{6}$ & Population density, per $\mathrm{km}^{2}$ & FC mean & FC extreme \\
\hline Norway & 385.2 & 11880 & 5.433 & 13.9 & 12156 & 2930 \\
\hline Northern Sweden & 242.7 & 12148 & 1.185 & 4.9 & 4438 & 2082 \\
\hline Southern Sweden & 168.6 & 10115 & 9.142 & 54.2 & 15063 & 4676 \\
\hline Lithuania & 65.3 & 2180 & 2.794 & 43.1 & 8060 & 2410 \\
\hline Latvia & 64.6 & 3356 & 1.92 & 30.0 & 3185 & 673 \\
\hline Finland & 338.1 & 22218 & 5.518 & 16.3 & 37119 & 16777 \\
\hline Belarus & 207.6 & 7894 & 9.485 & 45.5 & 2016 & 383 \\
\hline Estonia & 45.2 & 2232 & 1.329 & 29.2 & 3999 & 961 \\
\hline Pskov region & 55.3 & 2148 & 0.642 & 11.6 & 2139 & 450 \\
\hline Novgorod region & 55.3 & 3528 & 0.634 & 11.5 & 3634 & 835 \\
\hline St. Petersburg region & 83.9 & 4667 & 1.814 & 21.6 & 1581 & 299 \\
\hline Tver region & 84.1 & 4413 & 1.284 & 15.2 & 3707 & 748 \\
\hline Republic of Karelia & 172.4 & 9850 & 0.624 & 3.42 & 4129 & 1223 \\
\hline Murmansk region & 144.9 & 5423 & 0.754 & 5.16 & 3399 & 906 \\
\hline Vologda region & 145.7 & 9980 & 1.177 & 8.1 & 6840 & 955 \\
\hline Archangelsk region & 587.4 & 21695 & 1.111 & 2.69 & 2770 & 514 \\
\hline Komi Republic & 415.9 & 28671 & 0.851 & 2.02 & 2008 & 315 \\
\hline
\end{tabular}


2018).

\subsection{Circulation indices and EBZ-wide fire activity}

We formulated a fire activity index (FAI) for the whole EBZ, as the sum of the normalized values of cluster-specific chronology of annually burned areas. We then correlated gridded temperature and precipitation fields with FAI to analyze the relative importance of two climate variables in controlling regional fire activity. We analyzed correlations of indices of atmospheric circulation (NAO, SNAO, PDO, AMO and various formulations of ENSO) on EBZ-wide fire activity index (later referred to as FAI), calculated as the sum of normalized values of the "best members" in each cluster, as identified in previous analyses. Since the June SNAO revealed the strongest correlation with FAI (see the Results section), we analyzed their association by Morlet wavelet analysis. The analyses were run on a non-smoothed chronology and was realized in the R package WaveletComp (Roesch and Schmidbauer, 2018).

\section{Results}

Since 1992, the fire cycles in the EBZ stayed at $\sim 10^{3-4}$ years (Table 1). We observed a large variability in the fire cycles calculated on the three most fire prone years in the respective unit, with the shortest cycles being recorded in the St. Petersburg region and the Komi Republic (1581 and 2008 years, respectively) and the longest - in Finland and Southern Sweden (37 119 and 15063 years, respectively). The clustering of administrative units in respect to their chronology of the annually burned areas, suggested the presence of homogenous groups of units along S-N and W-E gradients (Fig. 2). We identified five clusters with the most western cluster encompassing the Baltic States, Belarus and the Russian region of Pskov, and the most eastern cluster - the Republic of Komi, the Arkhangelsk and Murmansk regions. Although our clustering exercise was aimed primarily at reducing the number of chronologies for subsequent analyses, it resulted in the grouping of neighboring regions, pointing to the existence of sub-regional patterns of fire activity.
LFYs in each of the clusters were associated with the development of the high pressure cells over the regions in question in July, indicating climatic forcing of LFYs (Fig. 3). Contingency analysis indicated no longterm trend in the synchrony of LFYs observed simultaneously in several administrative units (Fig. 4): for both the LFY and MDC versions of analyses, the regression of event frequencies against the time was insignificant: for LFYs $\mathrm{R}^{2}=0.001, p=0.30$; and for MDC extremes $\mathrm{R}^{2}<$ $0.001, p=0.43$. We noted a pronounced decadal variability in the synchrony levels. The general lack of trend indicated that the evolution of climate over the EBZ did not lead to an increase in the geographical extent of positive pressure anomalies during the warmer season.

The dynamics of drought conditions over 1901-2017, as approximated by MDC, suggested that most of the changes in fire weather occurred during the start of the fire season. We documented a trend towards higher values of MDC western section of EBZ for the month of April (Fig. 5). For May, the positive trend was observed in a section of Northern Europe centered on the Baltic Sea and over the northern fridges of the EBZ (Fig. 5). Mid-season fire weather showed, however, no upward long-term trend over the majority of the EBZ. In fact, sections of the Scandinavian Peninsula appeared to show a decreasing MDC trend, specifically - over southern portion of Scandinavian Peninsula in July and on the northern tip of the Peninsula during the months of August and September. An upward trend in MDC values was also observed at the end of the fire season (month of September) in the south-western section of the study area. Trends in MDC during the summer months were largely absent, which would likely indicate the lack of a climatically driven trend in fire severity.

The variability in maximum summer MDC across the EBZ, as revealed by the PCA analysis, suggested the presence of two zones with contrasting drought conditions: one located over the Scandinavian Peninsula and the western fringes of North-West Russia and another one stretching over the central and eastern sections of the EBZ (Fig. 6). Concerns about a variation in climate data quality prevented analyses of geographic variability in July MDC values over the first part of the 20th century. During the summer months we observed strong correlation between FAI, on one side, and temperature, precipitation and MDC

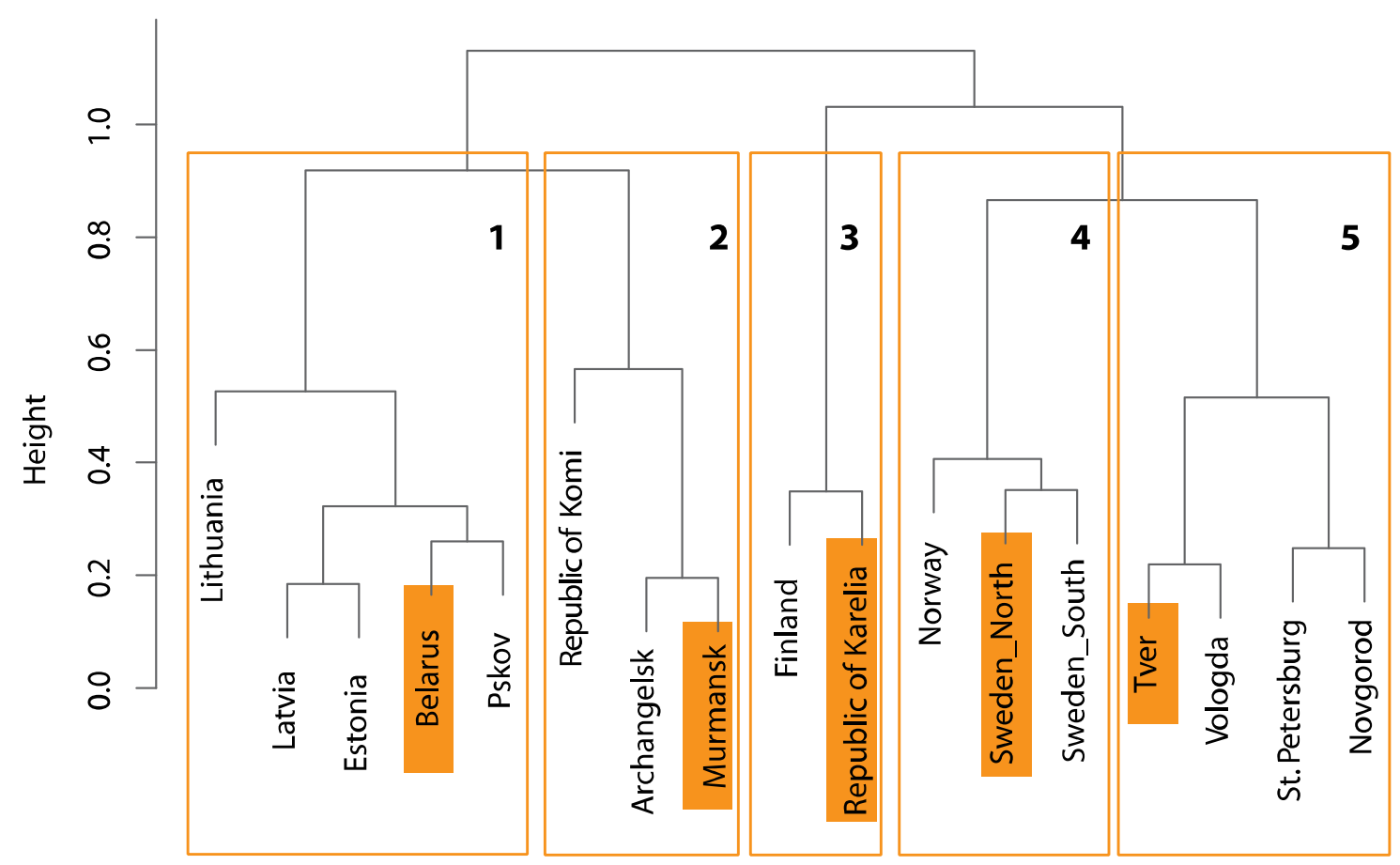

Fig. 2. Clustering of the composite (i.e. composed of both observational and reconstructed data) chronologies of the unit-specific amounts of burned forest area. Calculations were done on the PCA-transformed data and used the first five PCs. Colored backgrounds indicate the regions, which were considered as "the best representative" of that cluster for subsequent analyses. 


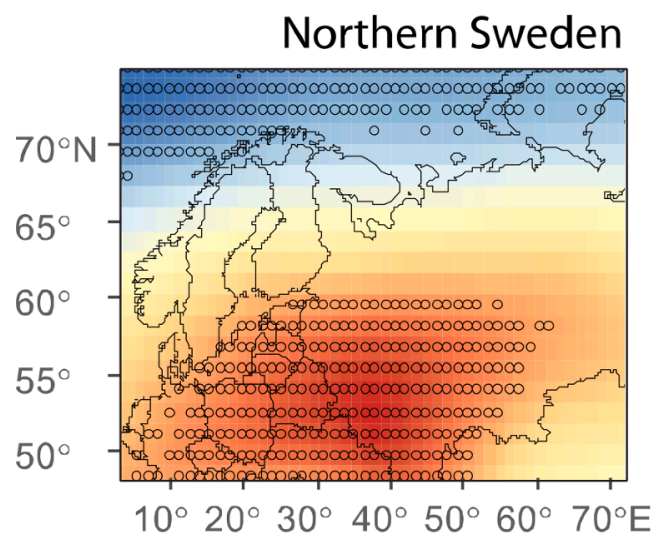

Tver region
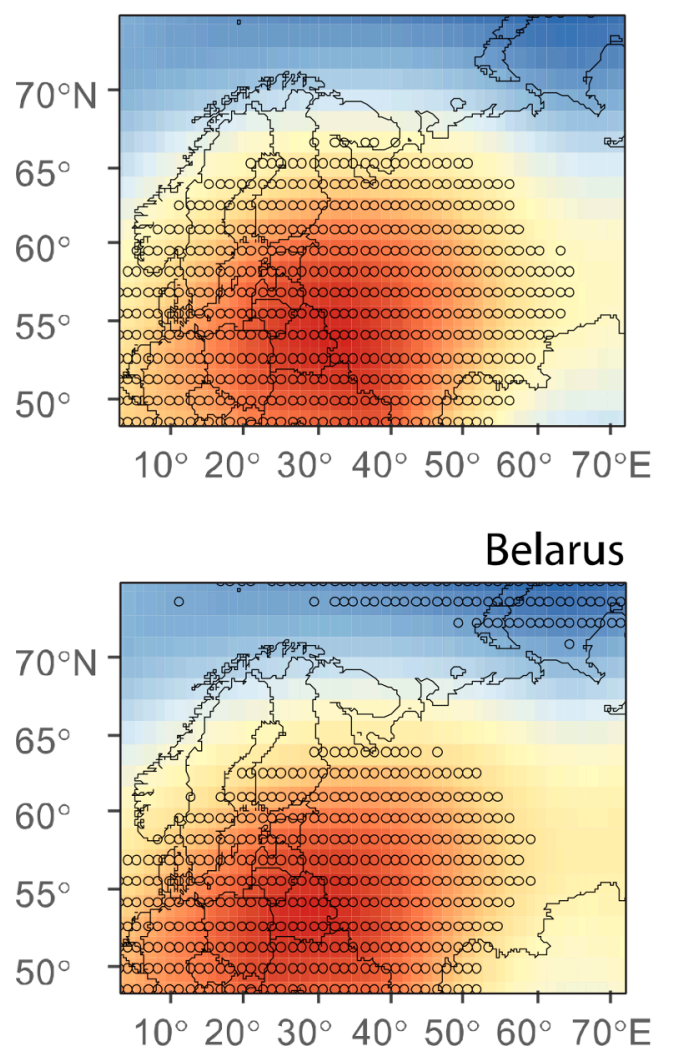

\section{Republic of Karelia}
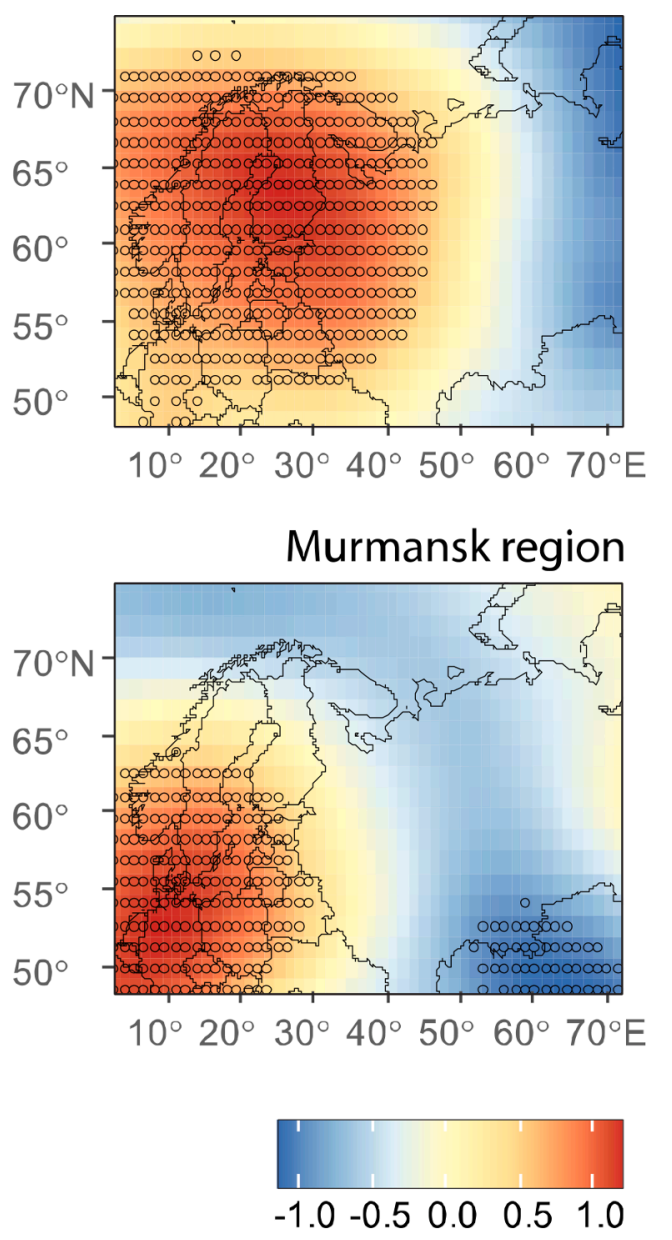

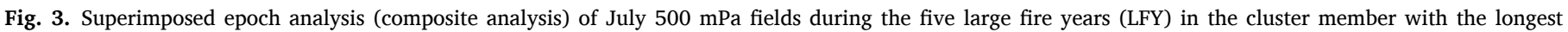
observational chronology. Significant departures are indicated with empty dots.

fields, on the other (Fig. 7). For the temperature fields, the areas of significant correlations were largely associated with the Scandinavian Peninsula and the south-western section of the EBZ. Significant correlations of FAI with precipitation tended to extend more to the eastern sections of EBZ, as compared with temperature fields. June and July were months when precipitation signal in the FAI was the strongest. MDC correlation field covered both the Scandinavian Peninsula and more eastern parts of the region with July and August being the months with the strongest correlations. The pattern apparently reflected response of regional fire activity to the accumulation of water deficit in the forest fuels towards the second half of the fire season.

FAI showed a positive association with the June summer NAO (SNAO) over the $1992-2017$ period (Fig. 8A and 8B). The wavelet coherence analysis conducted on composite (observational and reconstructed) values indicated that such positive association of two variables was mostly observed since the mid-1990s.
Correlations between monthly temperature fields and FAI varied in time and were most pronounced in June and July (Fig. 7). In June, we observed the positive association of two variables over the Fennoscandia (with the strongest correlation over Finland), Baltic States and western sections of the boreal zone in Russia. In July and August, the area with significant correlation decreased, its center being located over the southern part of the Baltic Sea. At the same time, negative correlation was observed over the eastern fringes of the study area during these two months. The strongest pattern associated with precipitation dynamics was the zone with negative correlations, centered over the Archangelsk region and stretching from Komi republic (in June) to south-western Norway (in July).

\section{Discussion}

A synthesis of EBZ fire activity over the $20^{\text {th }}$ century indicated a 


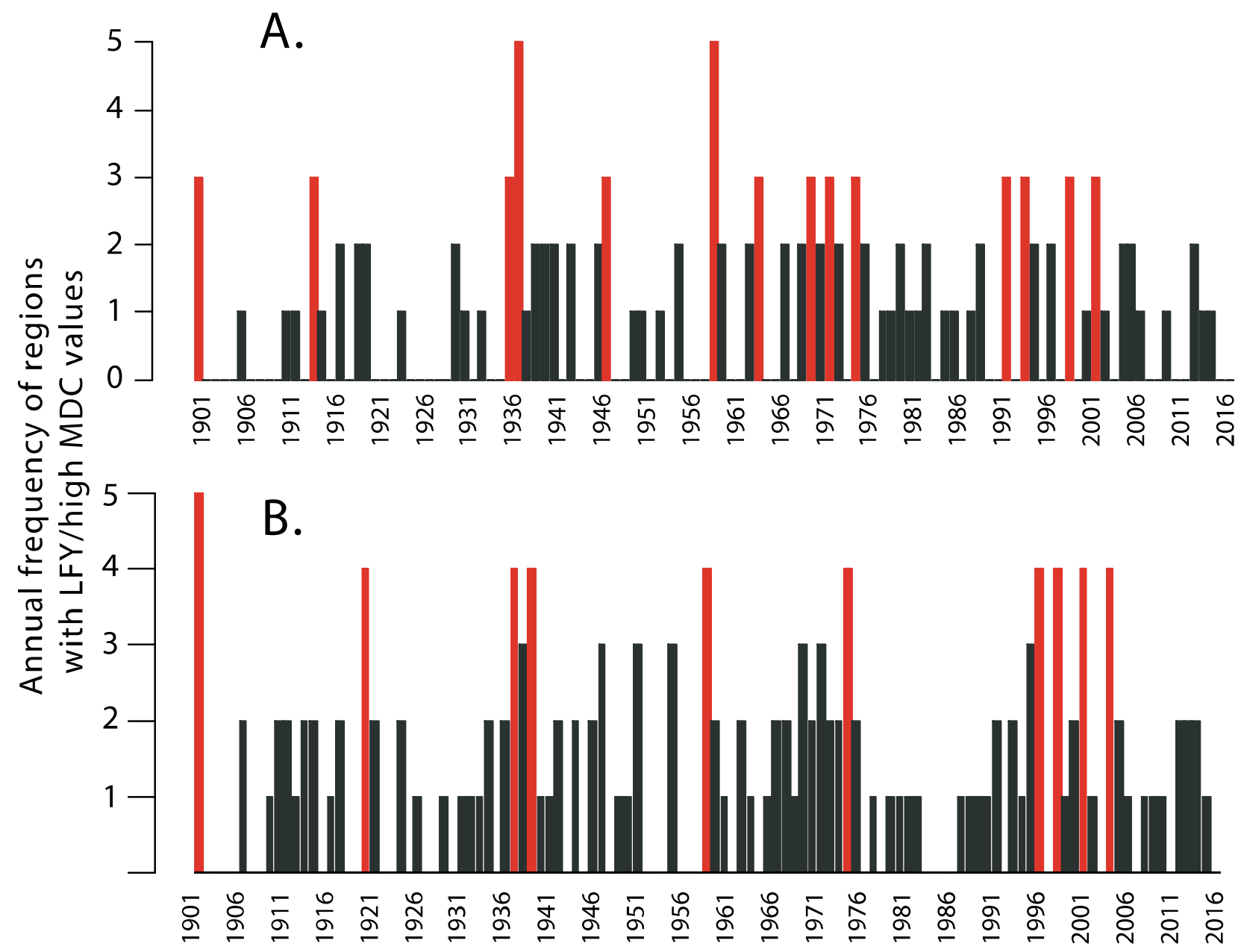

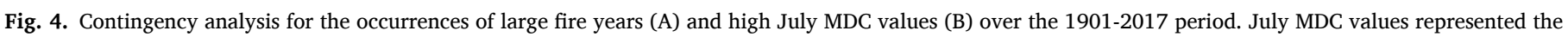

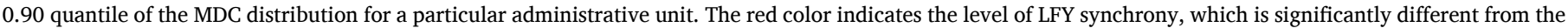
expectations assuming a random process, as estimated by the bootstrapping.

strong sub-regional pattern of fire-prone conditions and an apparent lack of the region-wide long-term trends, rejecting $\mathrm{H} 1$. We observed a century-long increase in the climatological fire hazard at the onset of the fire season in the western and northern sections of the EBZ, supporting H2. We observed a significant effect of SNAO on the EBZ-wide fire activity. The result confirmed $\mathrm{H} 3$ and pointed to a likely gradient in the impact of North-Atlantic atmospheric circulation on the forest fire activity across the EBZ. Overall, our results suggested that although being biogeographically similar (particularly - along the W-E gradient) the EBZ exhibits a certain degree of heterogeneity, in terms of its climatological fire hazard. We speculate that such heterogeneity might have also existed over longer temporal scales. Below we provide a detailed discussion of our finding.

\subsection{Pattern of forest fire cycles across EBZ}

The mean fire cycle in the studied administrative units varied between 1581 years (St. Petersburg region) and 37119 years (Finland) (Table 1). These estimates are one to two orders of magnitude longer than the fire cycles reconstructed across the Fennoscandia region prior to $1800 \mathrm{AD}$, when the fire cycle typically ranged between 50 and 300 years (Niklasson and Granström, 2000; Wallenius et al., 2010; Rolstad et al., 2017; Ryzhkova et al., 2020). Comparison of dendrochronologically-derived fire cycles with those based on the observational data is to be done with caution. The former tends to represent fire regimes of drier sections of the landscapes, where the decay of the deadwood preserving the scars from the historical fires, occurs at a slower rate. In contrast, regional observational data represents the diversity of forest types in respective regions and the calculation of the fire cycle, in this case, relies on the total forested area within a particular administrative unit. However, a similar scale of the differences between historical and $20^{\text {th }}$ and $21^{\text {st }}$ century fire cycles and large declines in fire activity has been documented in dendrochronological records (Niklasson and Granström, 2000; Wallenius, 2011; Storaunet et al., 2013; Ryzhkova et al., 2020). It indicates that the observed pattern is not a product of methodological bias.

The decline in fire activity at the century-long scale possibly had both climatic and human-related causes. Less fire-prone weather of the post Little Ice Age era (Bergeron and Archambault, 1993; Bergeron and Flannigan, 1995; Wallenius et al., 2007; Drobyshev et al., 2016), abandonment of land use patterns involving fire, and increasingly efficient fire suppression (Wallenius, 2011; Pinto et al., 2020) acted in concert to reduce forest fire hazard. The pattern of 25-year mean fire cycle did not exhibit a clear trend along a W-E gradient, although we acknowledge a likely variation in the quality of forest statistics, and specifically - a possible underestimation of fire activity in the Russian section of the EBZ (Shvidenko and Schepaschenko, 2013). This indicated that under non-fire prone years (which dominated during that period) the amount of forest burned in the studied administrative units is broadly comparable across the EBZ. However, the calculation of fire cycle on three unit-specific extreme fire years (i.e. the years with the largest amount of area burned during the period covered by 
April


August

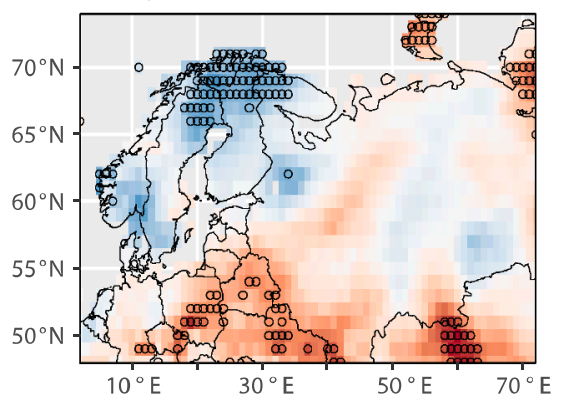

May



July

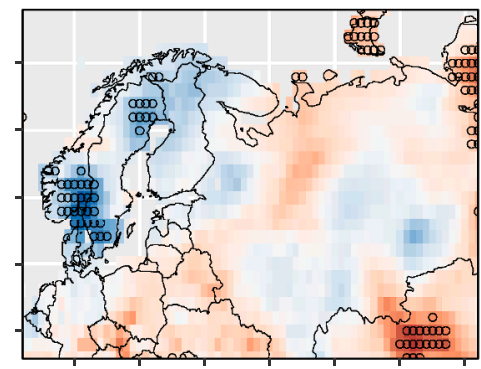

September

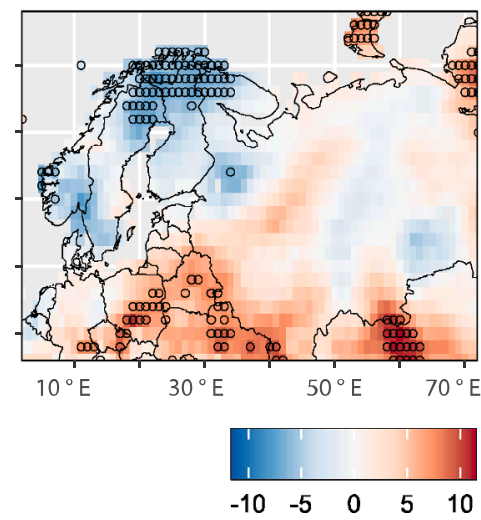

Fig. 5. Trends in MDC over the EBZ during the 20th and the early 21st centuries. The color refers to the direction of the trend, with positive trend indicated by the reddish colors and negative trend - by blueish colors. The trend is approximated by the value of the $b$ coefficient in the linear regression between cellspecific MDC chronologies and the global mean surface temperatures (GMST, Hansen et al., 2010) over 1901-2017. A significant ( $p<0.05)$ regression is indicated with the circle on top of respective cell. observational data) revealed striking differences between Fennoscandia and the Baltic States, on one hand, and the Russian regions, on another. While the fire cycle of western regions remained at the scale of one or a few thousand years, most of the Russian regions revealed fire cycles much below 1000 years, approaching the historic levels of fire activity reconstructed in Fennoscandia. This observation highlights two important considerations. First, a generally high amount of forested land and a lower density of human infrastructure, especially roads that facilitate the fire suppression work, discriminate the regions more clearly during the extreme fire years. Since the most "burnable" regions are also among the largest ones across the EBZ, this pattern should ultimately lead to a much higher contribution of eastern sections to the biome-wide balance of atmospheric concentrations of the trace gases, including carbon dioxide. Second, our data underpins the importance of the large fire years as the determinants of the cumulative estimates of regional fire activity. Indeed, the difference between long-term mean fire cycle and its "extreme version" reached approximately one order of magnitude in most regions (Table 1). It follows that the accurate modelling of the frequencies of extreme fire prone periods is of paramount importance to provide realistic estimates of the future fire activity.

The differences between a region-specific long-term mean fire cycle and its extreme version may potentially serve as a proxy for the efficiency of fire suppression activities. As the studied units feature similar climate and vegetation conditions, and, therefore, are broadly comparable, this approach may have the potential to facilitate econometric analyses aimed at optimizing prevention and suppression efforts. At the scale of the large units, differences in the severity of fire-prone weather may necessitate the weighting of such a proxy to better capture the "efficiency signal". However, for the analysis at finer spatial resolution (e.g. within single administrative regions), the high spatial autocorrelation of fire prone conditions will likely render such adjustment unnecessary, simplifying the analysis.

\subsection{Regional patterns of fire activity within EBZ and its climatic controls}

The clustering algorithm, although it was not constrained spatially, identified, nonetheless, geographically adjacent units of EBZ (Fig. 1). This indicated the presence of sub-regional patterns in fire activity, which overrode multiple non-climatic effects, such as varying levels of ignition frequencies, efficiency of forest fire management, as well as differences in forest structure, fuels and the quality of fire statistics across the administrative units.

Large fire years in each cluster were associated with the development of high-pressure cells. In Northern Europe, this pattern reflects warmer 

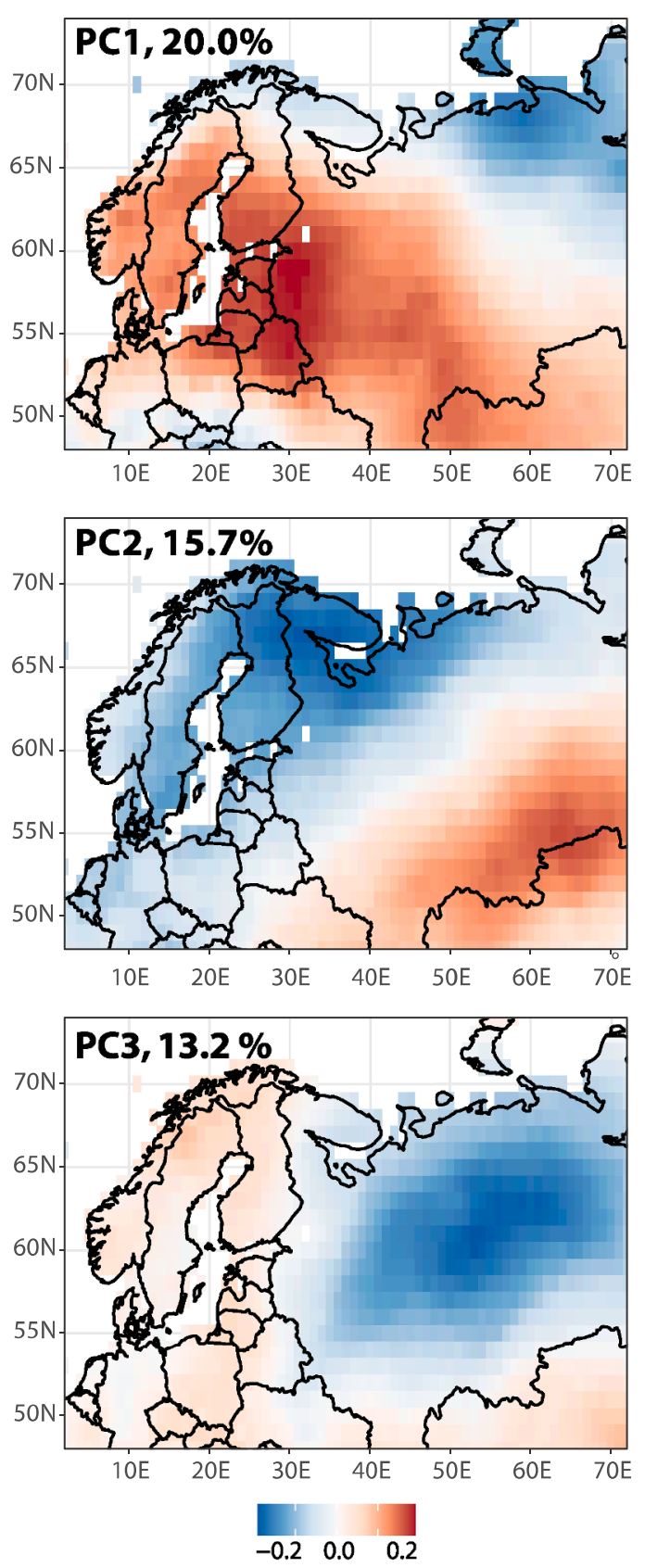

Fig. 6. Loadings of the first three PCs of the maximum summer MDC in the study region over the 1901-2017 period.

and drier weather conditions (Brunner et al., 2017; Schaller et al., 2018) leading to the rapid drying of forest fuels, preconditioning them for effective ignitions and fire spread (Johnson and Wowchuk, 1993; Fauria and Johnson, 2008). The association between positive pressure anomalies in the mid-tropospheric $(500 \mathrm{hPa})$ and periods of strong fire activity has been earlier demonstrated on the composite record of the Northern Swedish fire record, combining fire statistics and dendrochronological reconstructions (Drobyshev et al., 2015). Overall, the high pressure systems developing during the LFYs in specific clusters (Fig. 3) resembled summer versions of Scandinavian blocking, a daily weather regime identified on the winter time daily data (Cassou, 2008). We noted that although large fires years in every cluster were associated with a high-pressure cell in its proximity, these cells were often not centered on the cluster in question (Fig. 3). This was consistent with the observation that subsidence of the air is higher at the ridge edges, leading to more severe fire conditions through higher rates of fuel drying and stronger surface winds, both promoting fire spread (Fauria and Johnson, 2006; Hayasaka et al., 2019) and possibly also lightning activity (Price, 2009).

We did not reveal a century-long trend in the synchrony of LFY occurrence across EBZ and, similarly, no trend was visible for the MDC values indicative of the periods with strong fire hazard (Fig. 4). This result indicated that the geographical extent of high-pressure cells, likely correlated with the degree in the LFY synchrony, did not experience a directional change over the studied period. The general lack of EBZ-wide synchrony in the fire activity may be related to the presence of a dipole, i.e. the opposite behavior, of the fire weather, as revealed by the principle component analysis (Fig. 6). We detected such a dipole in respect to the values of the July MDC, which showed inverse loading of the first two principal components over the Scandinavian Peninsula and the eastern section of the EBZ. This pattern probably explains the asynchronous pattern of forest fire activity over the EBZ: while fireprone conditions occur over the Scandinavian Peninsula, wet conditions dominate over the areas in the vicinity of the western slopes of Ural Mountains. Consistent with this explanation was the occurrence of negative pressure anomalies in the vicinity of the Ural mountains during the years with strong fire activity and high pressure conditions in the most western of the identified clusters (Cluster 4 including Sweden and Norway, the first panel of Fig. 3). Similarly, an EBZ-wide index of fire activity suggested non-homogenous pattern of correlation with mean maximum temperatures over July and August, with the western sections of the EBZ exhibiting positive correlations, while the eastern sections the negative ones (Fig. 7). The mechanistic explanation of this pattern is unclear, although we speculate that the meandering pattern of the jet stream, controlling the intrusions of cold and dry Arctic air into the EBZ from the Arctic region, may be at play here. The absence of a trend in the synchronicity of LFYs and extreme MDC values over the 20th and early 21st centuries (Fig. 4) indirectly suggested that geographic localization of this dipole remained relatively stable over that period. Amplification of the jet stream's meandering pattern in the future (Coumou et al., 2018) may act towards increasing differences in fire weather among sub-regions of the EBZ during the fire season. This would make the region-wide LFYs less likely. In this context, the projected increase in the severity of the fire weather and frequencies of the extreme droughts in the boreal regions, including the European sector (Flannigan et al., 2009; de Groot et al., 2013), would likely have strong sub-regional signatures earlier demonstrated in the circumboreal analyses on the historical data (Girardin et al., 2009).

Although MDC dynamics did not suggest an EBZ-wide increase in the fire hazard, our results pointed to pronounced sub-regional and seasonal patterns of its dynamics (Fig. 5). A century-long increase in the summer MDC values occurred in the western section and northern sections of the EBZ and was limited to the spring period. This pattern may reflect an earlier onset of the warm season (Parmesan and Yohe, 2003; Menzel et al., 2006), increasing the temporal gap between the snow-free period and summer precipitation. The declining trend in the snow cover depth, observed in most of Finland over the 1961-2014 period (Luomaranta et al., 2019), is consistent with this observation. It is important to realize that drier spring conditions could be an important contributor to the state of forest fuels towards the second half of the fire season. An attribution study of the severe fire season in Sweden in 2018 suggested that spring drought was a likely precursor of the increase in fire activity in that year (Krikken et al., 2019). The increase in the forest fire hazard during early part of the fire season, observed in this study, was in agreement with the observation of an earlier onset of the fire season in other parts of the boreal domain (Hanes et al., 2019).

\subsection{Temperature and precipitation controls of EBZ fire activity}

Correlations between the regional fire activity index FAI, on one hand, and the warm season temperature and precipitation fields, on the 



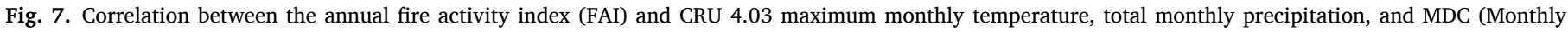
Drought Code) fields for May through August over the 1992-2017 period. Colored areas have a significance of the correlation coefficient at 0.10 or higher.

other, demonstrated a pattern consistent with strong control of drought conditions upon biome-wide and annually resolved fire activity (Fig. 7). Correlation between FAI and the maximum June temperature was significant over the whole Scandinavian Peninsula and included the areas which had the longest snow cover in the EBZ (Supp. Info. Fig. 1). In parallel, we observed a negative correlation between FAI and precipitation in the north of the Scandinavian Peninsula. The pattern began to appear already in May. Since the largest proportion of annually burned area there comes from the late season fires (Fig. 2B in the Drobyshev et al. 2012), the pattern we document here indicates the role of early season conditions in the accumulation of the water deficit in the forest fuels. Such predisposing of forest fuels to fire spread by spring and summer conditions appears to be characteristic of the northern regions of EBZ, as the area of significant associations for both temperature and precipitation moves southward during the fire season. We speculate that such a pattern indirectly points to the role of snow amounts and the speed of its disappearance as drivers of late-season fires.

The correlation structure of the maximum temperature field (Fig. 7) suggested a geographically non-homogenous pattern of correlation, with the eastern sections of the EBZ exhibiting negative association with FAI. This result was consistent with the observation of the dipole pattern in the loadings of MDC PCs, indicating the contrasting behavior of climatological fire hazard between the western and eastern sections of the EBZ (Fig. 6). Since the FAI is a cumulative measure of fire activity and is based on the fire statistics from single regions with the best data quality, it is expected that its correlation with climate variables should, to a certain degree, reflect the positions of these regions. It is, therefore, possible that the observed pattern might be, in part, caused by the fact that the "best members" of the regional clusters were located in the western section of the study area. In contrast, the association of FAI with precipitation revealed a much more coherent and geographically larger pattern, suggesting that that precipitation variability was the "synchronizing factor" in respect to the EBZ-wide forest fire activity. This is consistent with the analysis of climate-fire relationships on dendrochronologically reconstructed fire histories in a network of Northern European sites (Aakala et al., 2018). In particular, the authors of that study suggest regional precipitation patterns as a "credible determinant of fire synchrony" at the decadal scales.

\subsection{EBZ fire activity and SNAO}

The positive correlation between FAI and June SNAO pointed to the importance of atmospheric circulation in controlling forest fire activity over EBZ. As opposed to the NAO, which simply quantifies the northsouth pressure difference that conditions the strength of westerly winds across the Atlantic, the SNAO is, a representation of a "summer European blocking pattern" (Guemas et al., 2011) and defined as the first Empirical Orthogonal Function (EOF) of sea level pressure levels in the extratropical North Atlantic. The SNAO has been shown to be of critical importance in controlling drought periods in Europe (Folland et al., 2009). A positive SNAO state corresponds to an anticyclonic weather pattern and features a strong positive pressure anomaly centered over the Scandinavian Peninsula (Fig. 1 in (Folland et al., 2009)). We observed variations of this pattern in the analyses of LFYs for selected 

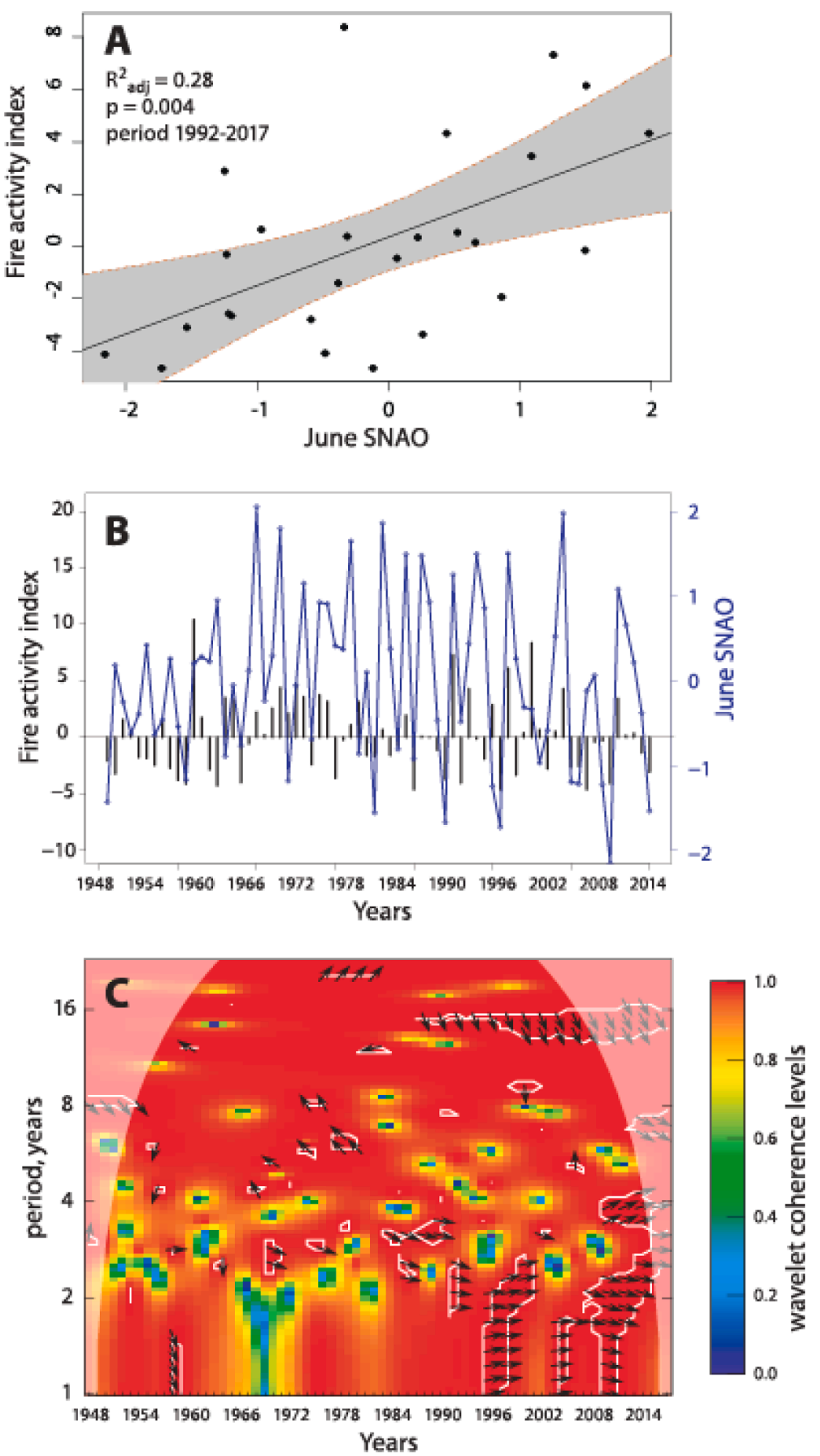

cluster members (Fig. 3). Of particular relevance for our study is a strong negative correlation between SNAO and precipitation (Figs. 4 and 6 in (Folland et al., 2009)), a pattern that is consistent with a strong negative correlation of July precipitation with FAI, an index representing EBZ-wide fire activity (Fig. 7).

A clear mechanistic link between SNAO and fire prone conditions in Northern Europe resulted in strong correlation between June SNAO and EBZ-wide FAI $\left(\mathrm{r}=0.53, \mathrm{p}<10^{-2}\right)$. We speculate that although SNAO captures a tangible amount of fire-related pressure variability in that
Fig. 8. Association between regional fire activity index (FAI) and June SNAO. A - linear regression between FAI and June SNAO over 1992-2017, with a 0.95 confidence envelope, adjusted $\mathrm{R}^{2}$ and significance indicated; B - annual chronologies of FAI (dark line) and June SNAO (blue line); C - Morlet bi-variate wavelet coherency analysis. Shown are the phase synchrony (horizontal arrows pointing to the right indicate in-phase variability at specific period), significance of coherence (areas circled with a thick white line), coherence levels indicated by color, and the time domain not affected by edge effects (the cone of influence). region, the large geographical extent of EBZ and the role of sub-regional weather patterns might be the factors limiting its predictive skill in respect to a EBZ-wide index, as suggested by the geographical pattern of loadings of the first three PCs of July MDC (Fig. 6). In the spectral analysis of SNAO and FAI, we observed the strongest correlation at nearannual scales and since the 1990s (Fig. 8). It is unclear what could be a driver of this pattern. Since the majority of the regional fire records were the reconstructed time series prior to 1992, there is a possibility that the change in significance reflected a transition from the observational to 
predominantly reconstructed sections of the chronologies.

\section{Conclusion}

Despite exhibiting strong gradients in climate conditions, modern and historical patterns of forest use, the infrastructure and human population densities, the forest fire activity of the European boreal zone remains strongly connected to the annual climate variability. Scale-wise, the levels of modern fire activity across the EBZ (Table 1) is one to two orders of magnitude lower than those reconstructed dendrochronologically for the 1500-1700 period. Such reconstructions mostly cover the northern sections of the EBZ and may overestimate historical fire activity, by preferentially relying on the data from drier parts of the sampled landscapes. However, the scale of the differences and the fact that the dendrochronological reconstructions themselves capture the decline in the burned areas, support the notion that the EBZ features historically low levels of fire activity. A non-homogenous pattern of fire prone conditions across the EBZ suggests an equally non-homogenous response of fire activity to the future climate variability. However, it is likely that a higher frequency of strongly positive SNAO states in the future will synchronize years with large areas burned across the EBZ. Analyses of the seasonal evolution of fire prone conditions is of immediate value for partitioning annual long-term trends in fire activity. Despite a cumulative nature of the strong droughts, a critical prerequisite of fire with largest ecological and economic impacts, there is a certain degree of independence between early- vs. late-season fire weather conditions (Duffy et al., 2005; Hayasaka et al., 2020), which is worth exploring in the future studies. The current study did not explore the link between the ocean SST temperatures and fire activity, although such a relationship has been documented for both North American (Shabbar et al., 2011) and Scandinavian (Drobyshev et al., 2016) boreal regions, and these analyses are well-warranted.

\section{Declaration of Competing Interest}

Authors declare no conflict of interests.

\section{Acknowledgements}

The study was supported by the Stiftelsen Stina Werners Foundation (grant \# SSWF-17-3-Chdre), The Belmont Forum through consortium PREREAL (grant \# 292_292-2015-11-30-13-43-09), the grant from the Russian Foundation for Basic Research (grant \# 20-04-00568), The Swedish Institute through the BalticFire network (grant \# 24474/2018), CBC KolArctic project IMPRESS (\# KO4040), and state order to the Karelian Research Centre of the Russian Academy of Sciences (Forest Research Institute KRC). We thank Prof. J. William Munger and two anonymous reviewers for constructive comments on an earlier version of the paper. This paper is a publication of the SNS NordicProxy and GDRI ColdForests networks.

\section{Supplementary materials}

Supplementary material associated with this article can be found, in the online version, at doi:10.1016/j.agrformet.2021.108467.

\section{References}

Aakala, T., Pasanen, L., Helama, S., Vakkari, V., Drobyshev, I., Seppä, H., Kuuluvainen, T., Stivrins, N., Wallenius, T., Vasander, H., Holmström, L., 2018. Multiscale variation in drought controlled historical forest fire activity in the boreal forests of eastern Fennoscandia. Ecol. Monogr. 88 https://doi.org/10.1002/ ecm.1276.

Ahti, T., Hämet-Ahti, L., Jalas, J., 1968. Vegetation zones and their sections in northwestern Europe. Ann.Bot.Fenn 5, 169-211.

Aleksandrova, V.D., Yurkovskaya, T.K., 1989. Geobotanical zoning of the nonChernozem zone of the European part of the USSR. Nauka Publshing House, Leningrad (St. Petersburg).
Allan, R., Ansell, T., 2006. A new globally complete monthly historical gridded mean sea level pressure dataset (HadSLP2): 1850-2004. J. Clim. 19, 5816-5842.

Bergeron, Y., Archambault, L., 1993. Decreasing frequency of forest fires in the southern boreal zone of Quebec and its relation to global warming since the end of the "Little Ice Age". Holocene 3, 255-259.

Bergeron, Y., Flannigan, M.D., 1995. Predicting the effects of climate-change on fire frequency in the southeastern Canadian boreal forest. Water Air Soil Pollut 82, 437-444.

Brunner, L., Hegerl, G.C., Steiner, A.K., 2017. connecting atmospheric blocking to European temperature extremes in spring. J. Clim. 30, 585-594. https://doi.org/ 10.1175/JCLI-D-16-0518.1.

Carcaillet, C., Bergman, I., Delorme, S., Hornberg, G., Zackrisson, O., 2007. Long-term fire frequency not linked to prehistoric occupations in northern Swedish boreal forest. Ecology 88, 465-477.

Cassou, C., 2008. Intraseasonal interaction between the Madden-Julian oscillation and the North Atlantic oscillation. Nature 455.

Clear, J.L., Molinari, C., Bradshaw, R.H., 2014. Holocene fire in Fennoscandia and Denmark. Int. J. Wildl. Fire 23, 781-789.

Conard, S.G., Ivanova, G.A., 1997. Wildfire in Russian boreal forests - potential impacts of fire regime characteristics on emissions and global carbon balance estimates. Environ. Pollut. 98, 305-313.

Cook, E.R., Briffa, K.R., Jones, P.D., 1994. Spatial regression methods in dendroclimatology - a review and comparison of 2 techniques. Int. J. Climatol. 14, 379-402.

Coumou, D., Di Capua, G., Vavrus, S., Wang, L., Wang, S., 2018. The influence of Arctic amplification on mid-latitude summer circulation. Nat. Commun. https://doi.org/ 10.1038/s41467-018-05256-8.

de Groot, W., Flannigan, M., Cantin, A.S., 2013. Climate change impacts on future boreal fire regimes. For. Ecol. Manage. 294, 35-44.

Drobyshev, I., Bergeron, Y., Girardin, M.P., Gauthier, S., Ols, C., Ojal, J., 2017. Strong gradients in forest sensitivity to climate change revealed by dynamics of forest fire cycles in the post little ice age era. J. Geophys. Res. Biogeosciences 122. https://doi. org/10.1002/2017JG003826.

Drobyshev, I., Bergeron, Y., Linderholm, H.W., Granström, A., Niklasson, M., 2015. A 700-year record of large fire years in northern Scandinavia shows large variability and increased frequency during the $1800 \mathrm{~s}$. J. Quat. Sci. 30, 211-221.

Drobyshev, I., Bergeron, Y., Vernal, A.D., Moberg, A., Ali, A.A., Niklasson, M., 2016. Atlantic SSTs control regime shifts in forest fire activity of Northern Scandinavia. Sci. Rep. 6 https://doi.org/10.1038/srep22532.

Drobyshev, I., Granström, A., Linderholm, H.W., Hellberg, E., Bergeron, Y., Niklasson, M., 2014. Multi-century reconstruction of fire activity in northern European boreal forest suggests differences in regional fire regimes and their sensitivity to climate. J. Ecol. 102 https://doi.org/10.1111/1365-2745.12235.

Drobyshev, I., Niklasson, M., 2004. Linking tree rings, summer aridity, and regional fire data: An example from the boreal forests of the Komi Republic, East European Russia. Can. J. For. Res. 34 https://doi.org/10.1139/X04-112.

Drobyshev, I., Niklasson, M., Linderholm, H.W., 2012. Forest fire activity in Sweden: Climatic controls and geographical patterns in 20th century. Agric. For. Meteorol. 154-155. https://doi.org/10.1016/j.agrformet.2011.11.002.

Duffy, P.A., Walsh, J.E., Graham, J.M., Mann, D.H., Rupp, T.S., 2005. Impacts of largescale atmospheric-ocean variability on Alaskan fire season severity. Ecol. Appl. 15, 1317-1330.

Eden, J.M., Krikken, F., Drobyshev, I., 2020. An empirical prediction approach for seasonal fire risk in the boreal forests. Int. J. Climatol. 40, 2732-2744. https://doi. org/10.1002/joc.6363.

Falk, D.A., Heyerdahl, E.K., Brown, P.M., Farris, C., Fule, P.Z., McKenzie, D., Swetnam, T. W., Taylor, A.H., Van Horne, M.L., 2011. Multi-scale controls of historical forest-fire regimes: new insights from fire-scar networks. Front. Ecol. Environ. 9, 446-454.

Fauria, M.M., Johnson, E.A., 2008. Climate and wildfires in the North American boreal forest. Philos. Trans. R. Soc. B-Biological Sci. 363, 2317-2329.

Fauria, M.M., Johnson, E.A., 2006. Large-scale climatic patterns control large lightning fire occurrence in Canada and Alaska forest regions. J. Geophys. Res. 111.

Flannigan, M.D., Krawchuk, M.A., de Groot, W.J., Wotton, B., Gowman, L.M., 2009. Implications of changing climate for global wildland fire. Int. J. Wildl. Fire 18, 483-507.

Folland, C.K., Knight, J., Linderholm, H.W., Fereday, D., Ineson, S., Hurrell, J.W., 2009. The summer North Atlantic Oscillation: past, present, and future. J. Clim. 22, 1082-1103.

Gauthier, S., Bernier, P., Kuuluvainen, T., Shvidenko, A., Schepaschenko, D., 2015. Boreal forest health and global change. Science (80-.) 349, 819-822.

Giglio, L., Randerson, J.T., van der Werf, G.R., 2013. Analysis of daily, monthly, and annual burned area using the fourth-generation global fire emissions database (GFED4). J. Geophys. Res. 118, 317-328.

Girardin, M.P., Ali, A., Carcaillet, C., Mudelsee, M., Drobyshev, I., Hély, C., Bergeron, Y., 2009. Heterogeneous response of circumboreal wildfire risk to climate change since the early 1900s. Glob. Chang. Biol. 15 https://doi.org/10.1111/j.13652486.2009.01869.x.

Girardin, M.P., Wotton, B.M., 2009. Summer moisture and wildfire risks across Canada. J. Appl. Meteorol. Climatol. 48, 517-533.

Granström, A., 1993. Spatial and temporal variation in lightning ignitions in Sweden. J. Veg. Sci. 4, 737-744.

Granström, A., Niklasson, M., 2008. Potentials and limitations for human control over historic fire regimes in the boreal forest. Philos. Trans. R. Soc. B-Biological Sci. 363, 2353-2358.

Greisman, A., Gaillard, M.J., 2009. The role of climate variability and fire in early and mid Holocene forest dynamics of southern Sweden. J. Quat. Sci. 24, 593-611. 
Guemas, V., Salas-Melia, D., Kageyama, M., Giordani, H., Voldoire, A., SanchezGomez, E., 2011. Summer interactions between weather regimes and surface ocean in the North-Atlantic region. Clim. Dyn. 36, 1629.

Hanes, C.C., Wang, X., Jain, P., Parisien, M.A., Little, J.M., Flannigan, M.D., 2019. Fireregime changes in Canada over the last half century. Can. J. For. Res. 49, 256-269. https://doi.org/10.1139/cjfr-2018-0293.

Hansen, J., Ruedy, R., Sato, M., Lo, K., 2010. Global surface temperature change. Rev. Geophys. 48, RG4004. https://doi.org/10.1029/2010RG000345.

Harris, I., Jones, P.D., Osborn, T.J., Lister, D.H., 2014. Updated high-resolution grids of monthly climatic observations - the CRU TS3.10 Dataset. Int. J. Climatol. 34, 623-642.

Hayasaka, H., Sokolova, G.V., Ostroukhov, A., Naito, D., 2020. Classification of active fires and weather conditions in the lower amur river basin. Remote Sens. 12, 1-17. https://doi.org/10.3390/rs12193204.

Hayasaka, H., Yamazaki, K., Naito, D., 2019. Weather conditions and warm air masses during active fire-periods in boreal forests. Polar Sci. 22, 100472 https://doi.org/ 10.1016/j.polar.2019.07.002.

Johnson, E.A., Wowchuk, D.R., 1993. Wildfires in the southern Canadian Rockymountains and their relationship to midtropospheric anomalies. Can. J. For. Res. Can. Rech. For. 23, 1213-1222.

Kelly, P.M., Sear, C.B., 1984. Climatic impact of explosive volcanic eruptions. Nature 311, 740-743.

Kharuk, V.I., Ponomarev, E.I., Ivanova, G.A., Dvinskaya, M.L., Coogan, S.C.P., Flannigan, M.D., 2021. Wildfires in the Siberian taiga. Ambio. https://doi.org/ 10.1007/s13280-020-01490-x.

Krikken, F., Lehner, F., Hausten, K., Drobyshev, I., van Oldenborgh, G., 2019. Attribution of the role of climate change in the forest fires in Sweden 2018. Nat. Hazards Earth Syst. Sci. https://doi.org/10.5194/nhess-2019-206.

Larjavaara, M., Pennanen, J., Tuomi, T.J., 2005. Lightning that ignites forest fires in Finland. Agric. For. Meteorol. 132, 171-180.

Lehtonen, I., Venalainen, A., Kamarainen, M., Peltola, H., Gregow, H., 2016. Risk of large-scale fires in boreal forests of Finland under changing climate. Nat. Hazards Earth Syst. Sci. 16, 239-253.

Luomaranta, A., Aalto, J., Jylhae, K., 2019. Snow cover trends in Finland over 1961-2014 based on gridded snow depth observations. Int. J. Climatol. 39, 3147-3159. https:// doi.org/10.1002/joc.6007.

Menzel, A., Sparks, T.H., Estrella, N., Koch, E., Aasa, A., Ahas, R., Alm-Kuebler, K., Bissolli, P., Braslavska, O., Briede, A., Chmielewski, F.M., Crepinsek, Z., Curnel, Y., Dahl, A., Defila, C., Donnelly, A., Filella, Y., Jatcza, K., Mage, F., Mestre, A., Nordli, O., Penuelas, J., Pirinen, P., Remisova, V., Scheifinger, H., Striz, M., Susnik, A., Van Vliet, A.J.H., Wielgolaski, F.-E., Zach, S., Zust, A., 2006. European phenological response to climate change matches the warming pattern. Glob. Chang. Biol. 12, 1969-1976. https://doi.org/10.1111/j.1365-2486.2006.01193.x.

Niklasson, M., Granström, A., 2000. Numbers and sizes of fires: Long-term spatially explicit fire history in a Swedish boreal landscape. Ecology 81, 1484-1499.

Ohlson, M., Brown, K.J., Birks, H.J.B., Grytnes, J.A., Hornberg, G., Niklasson, M., Seppa, H., Bradshaw, R.H.W., 2011. Invasion of Norway spruce diversifies the fire regime in boreal European forests. J. Ecol. 99, 395-403.

Parmesan, C., Yohe, G., 2003. A globally coherent fingerprint of climate change impacts across natural systems. Nature 421, 37-42.

Pitkanen, A., Huttunen, P., 1999. A 1300-year forest-fire history at a site in eastern Finland based on charcoal and pollen records in laminated lake sediment. Holocene 9, 311-320.

Prentice, I.C., Sykes, M.T., Cramer, W., 1991. The possible dynamic-response of northern forests to global warming. Glob. Ecol. Biogeogr. Lett. 1, 129-135.

Price, C., 2009. Thunderstorms, lightning and climate change. In: Betz, H.D., Schumann, U., Laroche, P. (Eds.), Lightning: Principles, Instruments and
Applications: Review of Modern Lightning Research. Springer Science + Business Media B.V., pp. 521-535

Pinto, G.A.S.J., Rousseu, F., Niklasson, M., Drobyshev, I., 2020. Effects of human-related and biotic landscape features on the occurrence and size of modern forest fires in Sweden. Agric. For. Meteorol. 291.

R Development Core Team, 2018. R: A language and environment for statistical computing. R Foundation for Statistical Computing, Vienna, Austria.

Roesch, A., Schmidbauer, H., 2018. WaveletComp: computational wavelet analysis.

Rolstad, J., Blanck, Y.L., Storaunet, K.O., 2017. Fire history in a western Fennoscandian boreal forest as influenced by human land use and climate. Ecol. Monogr. 87, 219-245.

Ruosteenoja, K., Markkanen, T., Venäläinen, A., Räisänen, P., Peltola, H., 2018. Seasonal soil moisture and drought occurrence in Europe in CMIP5 projections for the 21st century. Clim. Dyn. 50, 1177-1192. https://doi.org/10.1007/s00382-017-3671-4.

Ryzhkova, N., Pinto, G., Kryshen', A., Bergeron, Y., Ols, C., Drobyshev, I., 2020. Multicentury reconstruction suggests complex interactions of climate and human controls of forest fire activity in a Karelian boreal landscape, North-West Russia. For. Ecol. Manage. 459 https://doi.org/10.1016/j.foreco.2019.117770.

Schaller, N., Sillmann, J., Anstey, J., Fischer, E.M., Grams, C.M., Russo, S., 2018. Influence of blocking on Northern European and Western Russian heatwaves in large climate model ensembles. Environ. Res. Lett. 13 https://doi.org/10.1088/17489326/aaba55.

Schimmel, J., Granström, A., 1996. Fire severity and vegetation response in the boreal Swedish forest. Ecology 77, 1436-1450.

Shabbar, A., Skinner, W., Flannigan, M.D., 2011. Prediction of seasonal forest fire severity in Canada from large-scale climate patterns. J. Appl. Meteorol. Climatol. 50, 785-799.

Shvidenko, A.Z., Schepaschenko, D.G., Flannigan, M.D., 2013. Climate change and wildfires in Russia. Contemp. Probl. Ecol. 6, 683-692.

Skinner, W.R., Stocks, B.J., Martell, D.L., Bonsal, B., Shabbar, A., 1999. The association between circulation anomalies in the mid-troposphere and area burned by wildland fire in Canada. Theor. Appl. Climatol. 63, 89-105.

Soja, A.J., Cofer, W.R., Shugart, H.H., Sukhinin, A.I., Stackhouse, P.W., Mcrae, D.J., Conard, S.G., 2004. Estimating fire emissions and disparities in boreal Siberia (19982002). J. Geophys. Res. 109.

Sokal, R.R., Rolf, F.J., 1995. Biometry: the principles and practice of statistics in biological research. W. H. Freeman, New York.

Stocks, B.J., Fosberg, M.A., Lynham, T.J., Mearns, L., Wotton, B.M., Yang, Q., Jin, J.Z., Lawrence, K., Hartley, G.R., Mason, J.A., McKenney, D.W., 1998. Climate change and forest fire potential in Russian and Canadian boreal forests. Clim. Change 38, $1-13$.

Storaunet, K.O., Rolstad, J., Toeneiet, M., Blanck, Y.L., 2013. Strong anthropogenic signals in historic forest fire regime: a detailed spatiotemporal case study from southcentral Norway. Can. J. For. Res. Can. Rech. For. 43, 836-845.

Swetnam, T.W., 1993. Fire history and climate-change in Giant Sequoia groves. Science (80-.) 262, 885-889.

Turner, J.A., 1972. The Drought Code Component of the Canadian Forest Fire Behaviour System. Environment Canada, Ottawa, Ontario, Canada.

Wallenius, T., 2011. Major Decline in Fires in Coniferous Forests - Reconstructing the Phenomenon and Seeking for the Cause. Silva Fenn 45, 139-155.

Wallenius, T., Kauhanen, H., Herva, H., Pennanen, J., 2010. Long fire cycle in northern boreal Pinus forests in Finnish Lapland. Can. J. For. Res. Can. Rech. For. 40, 2027-2035.

Wallenius, T.H., Lilja, S., Kuuluvainen, T., 2007. Fire history and tree species composition in managed Picea abies stands in southern Finland: Implications for restoration. For. Ecol. Manage. 250, 89-95.

Zang, C., Biondi, F., 2015. treeclim: an R package for the numerical calibration of proxyclimate relationships. Ecography (Cop.) 38, 431-436. 